Article

\title{
An Improved Evaluation Scheme for Performing Quality Assessments of Unconsolidated Cultivated Land
}

\author{
Lina Peng ${ }^{1,2}$, Yan $\mathrm{Hu}^{2,3}$, Jiyun $\mathrm{Li}^{4}$ and Qingyun $\mathrm{Du}^{1,5,6, *}$ \\ 1 School of Resource and Environmental Science, Wuhan University, 129 Luoyu Road, Wuhan 430079, China; \\ linapeng@whu.edu.cn \\ 2 Wuhan Hongfang Real Estate \& Land Appraisal. Co, Ltd., Room 508, District C, International Headquarters, \\ Han Street, Wuchang District, Wuhan 430061, China; hongfangchina@aliyun.com \\ 3 School of Logistics and Engineering Management, Hubei University of Economics, 8 Yangqiao Lake Road, \\ Canglongdao Development Zone, Jiangxia District, Wuhan 430205, China \\ 4 School of Urban and Environmental Sciences, Central China Normal University, 152 Luoyu Road, Wuhan \\ 430079, China; realc12@mails.ccnu.edu.cn \\ 5 Key Laboratory of GIS, Ministry of Education, Wuhan University, 129 Luoyu Road, Wuhan 430079, China \\ 6 Key Laboratory of Digital Mapping and Land Information Application Engineering, National \\ Administration of Surveying, Mapping and Geo-information, Wuhan University, 129 Luoyu Road, \\ Wuhan 430079,China \\ * Correspondence: qydu@whu.edu.cn; Tel.: +86-27-6877-8842; Fax: +86-27-6877-8893
}

Received: 5 June 2017; Accepted: 21 July 2017; Published: 27 July 2017

\begin{abstract}
Socioeconomic factors are extrinsic factors that drive spatial variability. They play an important role in land resource systems and sometimes are more important than that of the natural setting. The study aims to build a comprehensive framework for assessing unconsolidated cultivated land (UCL) in the south-central and southwestern portions of Hubei Province, China, which have not experienced project management and land consolidation, to identify the roles of natural and especially socioeconomic factors. Moreover, the study attempts to identify the attributes and indicators that describe the characteristics of the extrinsic factors affecting land spatial variability. Assessment supplement 12 proposed land use indicators on the basis of natural factors using the method of gradation of agricultural land quality (GALQ). The overall level of cultivated land quality (CLQ) in the two study areas is moderate, and this quantity is significantly correlated with topography. Excellent and high-quality UCL are mainly distributed in the south-central plain division of Hubei Province (SCPDHP), whereas lower grades are mainly distributed in the area of the southwestern mountainous division of Hubei Province (SWMDHP). These results suggest that the pattern of small-scale agricultural development depends strongly on the labor force and is the key land use-related factor that limits the improvement of regional CLQ. Such assessments and their findings are essential for the protection of cultivated land and the adjustment of agricultural structure to promote the sustainable use of UCL.
\end{abstract}

Keywords: spatial variability; unconsolidated cultivated land (UCL); comprehensive assessment of cultivated land quality; land use and production conditions (LUPCs); sustainable land management

\section{Introduction}

Declines in land quality caused by inappropriate land use and management practices are concerned to be an environmental and economic point [1-3]. The cultivated land system is a synthesis of natural and socioeconomic factors [4]. The interactions among these factors have an effect on land quality. Natural factors are usually intrinsic, substantial and relatively stable, whereas socioeconomic 
factors are extrinsic, invisible and dynamic [1]. Spatial variability in landscapes arises from a combination of intrinsic and extrinsic factors, while temporal variability is mainly up to changes in soil characteristics and rainfall patterns overtime [5]. Intrinsic spatial variability refers to natural variations in soil characteristics. These variations are related to soil formation processes, such as weathering, erosion and deposition [6]. Meanwhile, extrinsic spatial variability refers to variations caused by a lack of uniformity in management practices, e.g., tillage, chemical application and irrigation $[6,7]$. Exploitation of natural resources, including land, leads to degradation and is also stimulated by socioeconomic and political issues. Examples of such issues include land tenure and lack of capital [8,9].

To date, considerable research has been conducted on the intrinsic spatial variability of soil properties that is closely related to soil quality. Scientific interest in the spatial variability in field soils dates back to the early 1890 s $[10,11]$, and the study on soil variability in a systematic way was carried out through the 1960s and 1970s [12,13]. Over the years, various indicators have been identified in the literature. E.g. regarding to field-scale soil water properties, the study of Nielsen et al. [14] firstly demonstrated large variations in hydraulic conductivity values and infiltration rates from location to location. Five factors, identified by $\mathrm{Xu}$ et al. [15], are critical in determining soil quality, specifically texture, organic matter, porosity, phosphorus and microstructure. Other researches, such as those that apply landscape function analysis (LFA), base their assessments on surface hydrological properties, i.e., infiltration, erosion, rainfall, runoff, plant growth and nutrient cycling [16].

Land evaluation, which attempts to predict the behavior of land for particular uses, is different from soil quality assessment, because the soil biological parameters are not considered in land evaluation [17]. The realistic assessment of CLQ depends on identification of the variables, which is crucial to the sustainable use of regional land resources [1]. With the rapid development in rural society, socioeconomic factors are playing an important role in the land resource system and are more important than that of the natural setting sometimes [1]. Following the FAO framework for land evaluation and the subsequent literature, socioeconomic factors have been more emphasized in land-quality evaluations [18]. For example, changes in extrinsic spatial variability of selected macronutrients $(\mathrm{Ca}, \mathrm{Mg}, \mathrm{K}$, and $\mathrm{P}$ ) in surface (sandy) soils that resulted from tillage and fertilizer application were examined by Nkedi-Kizza et al. [19]. Dumanski [20] identified five sets of short-term indicators (nutrient balance, land use intensity, yield trends and variability, land use diversity and land cover) and three sets of long-term indicators (soil quality, agrobiodiversity and land degradation), as well as forest land quality, water quality, land contamination/pollution and range land quality. Thus, considerable research that characterizes intrinsic spatial variability has been performed, whereas fewer studies were carried on the spatial variability of cultivated land caused by extrinsic factors [6]. To improve the understanding on spatial variability in field soils, more studies on addressing extrinsic and intrinsic variations were proposed by Rao and Wagenet [5]. Currently, such studies are still lacking.

The equilibrium of land quality is easily disturbed by human activities, such as land consolidation and the behavior of farmers [21]. The effects of these activities are especially noticeable in China in recent years; the overall CLQ has tended to decline and urban areas and the economy have seen rapid development. Because land consolidation is an extremely efficient method of preventing land parcels from being broken up and ameliorating existing difficulties, the consolidative cultivated land (CCL) can be defined as cultivated land being rearranged and taken precautionary measures to ensure more fruitful working of land areas on the basis of developing agricultural technology [22,23]. Scholars and industry have carried out a large number of relevant studies in the past thirty years on the changes in the quality of consolidated cultivated land (CCL) and the factors that drive such changes. For instance, Cay [24] applied the analytic hierarchy process (AHP) to the reallocation process of land consolidation and evaluated the reallocation criteria and results. Caroline et al. [25] quantified and modeled the effect of land consolidation and field borders about soil redistribution in agricultural landscapes. Coelho et al. [26] presented a model that incorporates methods for the evaluation of performing agricultural systems before and after the transformations proposed in land consolidation projects. Tong Luyi [27] explored a method for the evaluation of cultivated land based on a current grading 
dataset for achieving a national balance between the requisition and compensation of cultivated land and identifying the impacts of land consolidation.

In China, a thematic strategy for the production of cultivated land called "Investigation and Evaluation of Cultivated Land Quality" is currently under development. First, the evaluation area is divided into two parts, depending on whether or not they were to experience land consolidation. In 2014, the 34 national provinces officially launched the evaluation of unconsolidated cultivated land (UCL) at the County level. In 2015, China carried out a comprehensive promotion of the implementation at the provincial level. The most important difference between UCL and CCL is that land consolidation is the main factor that causes the extrinsic spatial variability leading to changes in the CLQ of CCL, but not UCL. Within UCL, the natural factors are intrinsic and relatively stable, whereas the management practices of farmers, economic policies, and other factors maybe the key external driving forces in areas that have not experienced project investment and land consolidation. To date, we do not have a clear understanding of the changes in socioeconomic factors, although they sometimes play a more important role than natural factors.

Determining the internal and external factors that affect UCL, particularly the external factors, will help us to improve the land use conditions of CLQ more effectively. Moreover, it is also beneficial to combine UCL with land consolidation projects effectively. How to carry out a systematic evaluation of UCL that considers intrinsic and extrinsic factors has not been extensively studied, and empirical research is lacking.

Present work on the monitoring and evaluation of UCL still uses the evaluation system of GALQ that has been used in China since the early 2000s. However, the precision and real-time performance of this system, which is called "Global coverage," cannot fulfill the requirements of the increasing degree of land resource management because monitoring actual changes in land use conditions is difficult [27]. In addition, the pressure-state-response framework proposed by Dumanski and Pieri [28], which is based on the behavior of farmers, is difficult to employ to perform a regionally comparable assessment of CLQ. Consequently, it is urgent to establish a reliable and applicable evaluation system for assessing the quality of UCL.

Therefore, establishing criteria to determine [17] the quality of UCL and to develop indices is increasingly demanded. It may be used to rank and compare the quality of UCL at different locations or at the same location through time [28,29]. Moreover, it's desirable to evaluate the long-term potential limitations of these criteria and indices, and monitor the short-term changes reacting to land use and management practices [17].

The purpose of this study is to build a comprehensive assessment framework (CAF) of UCL for the south-central and southwestern portions of Hubei Province in China. The specific aims of this study are: (1) to identify the most useful socioeconomic indicators in the assessment by incorporating the natural factors [1]; (2) to design a comprehensive approach to achieve the objectives of land-quality evaluation and monitoring the quality of UCL; and (3) to explore the basic characteristics and spatial distribution of CLQ within the study area, as well as the degree of spatial differentiation, the limiting factors and the reasons underlying these patterns. The focus will be on how to conductive to the sustainability of land use and comprehensive management systems through conceiving the land-protection strategies.

\section{Constructing the Evaluation System}

\subsection{Evaluation Concepts}

The land-evaluation analysis concentrates on different purposes that can be grouped into two main classes, land vulnerability or degradation approaches and namely land suitability or productivity [17]. The gradation of agricultural land quality (GALQ) framework proposed by the Ministry of Land and Resources of China is the theoretical basis of this paper, which aims to assess land suitability or productivity. The calculation of natural quality grade is consistent with the GALQ method within the study area. In addition, the natural quality factors and their weights, as well as the solar and 
temperature potential productivity $(\alpha)$ and the yield ratio $(\beta)$, are kept unchanged. Thus, the land use and production conditions (LUPCs), which have a significant impact on the CLQ, are added [30]. In the process of evaluation, the land use coefficient is generally assessed as a constant value [30]. Using the concept of coefficient correction, we include the LUPCs (P) in the calculation of the land use correction index $K_{p}$ and reassess the grade of the CLQ (Figure 1). P can be converted to the land use correction coefficient using data obtained 2009 and 2014 and the corresponding annual scores. In the future, when more data are available, it will be better to use data that cover a longer time period to calculate the coefficient.

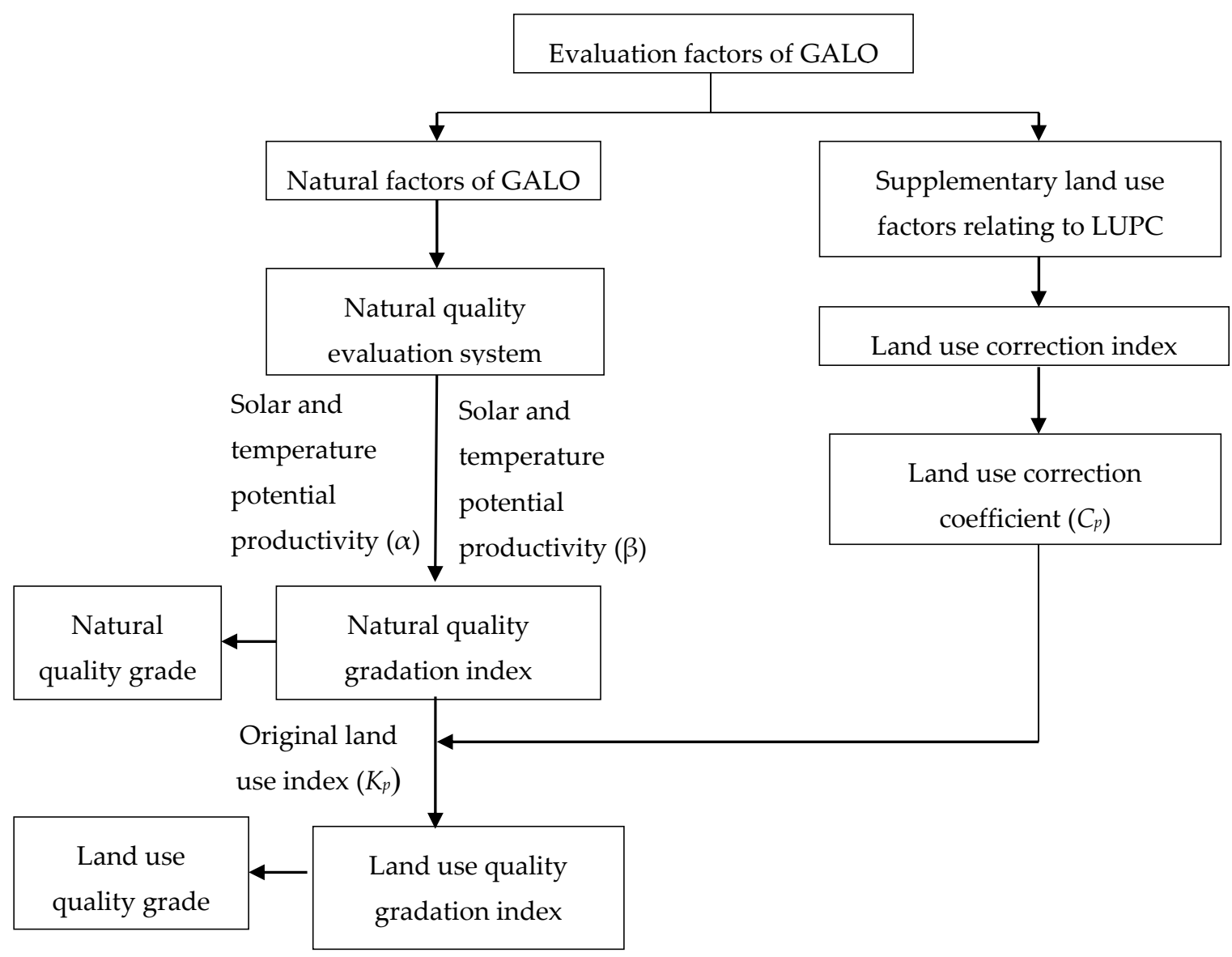

Figure 1. Flow chart used in the evaluation of cultivated land quality (CLQ).

\subsection{Selection of Assessment Indicators}

It is an essential part of land-evaluation analysis that to select the land characteristics (soil, crop/management factors and climate) as input variables or diagnostic indicators for the predictive models, and this selection lies in the issues under consideration [17]. As mentioned earlier, the natural (physical and chemical) quality indicators, such as organic matter, soil $\mathrm{pH}$, irrigation guarantee rate, drainage condition, groundwater depth, obstacle depth, profile configuration and soil pollution, are consistent with the GALQ and are used to assess the plain areas. In addition, topographic gradient, the amount of surface rock exposed and the degree of soil erosion are used to assess the mountainous areas.

To reveal the mechanisms by which LUPCs, including macro policy, farmer behavior and urbanization, affect CLQ and to meet the demands of land management for CLQ assessments over time, this article uses literature analysis $[27,30]$ and expert consultation [31] to choose the evaluation indicators that supplement six LUPC indicators, specifically infrastructure, traffic conditions, land investment intensity, resources, land use type and productivity conditions. The weights are determined 
using the improved AHP, which is a multi-criteria decision-making method [24] (Table 1). The improved AHP process solves not only the consistency problem of the judgment matrix, but also the problem of convergence speed and accuracy of the knowledge [24,32].

Table 1. Land use and production conditions (LUPCs).

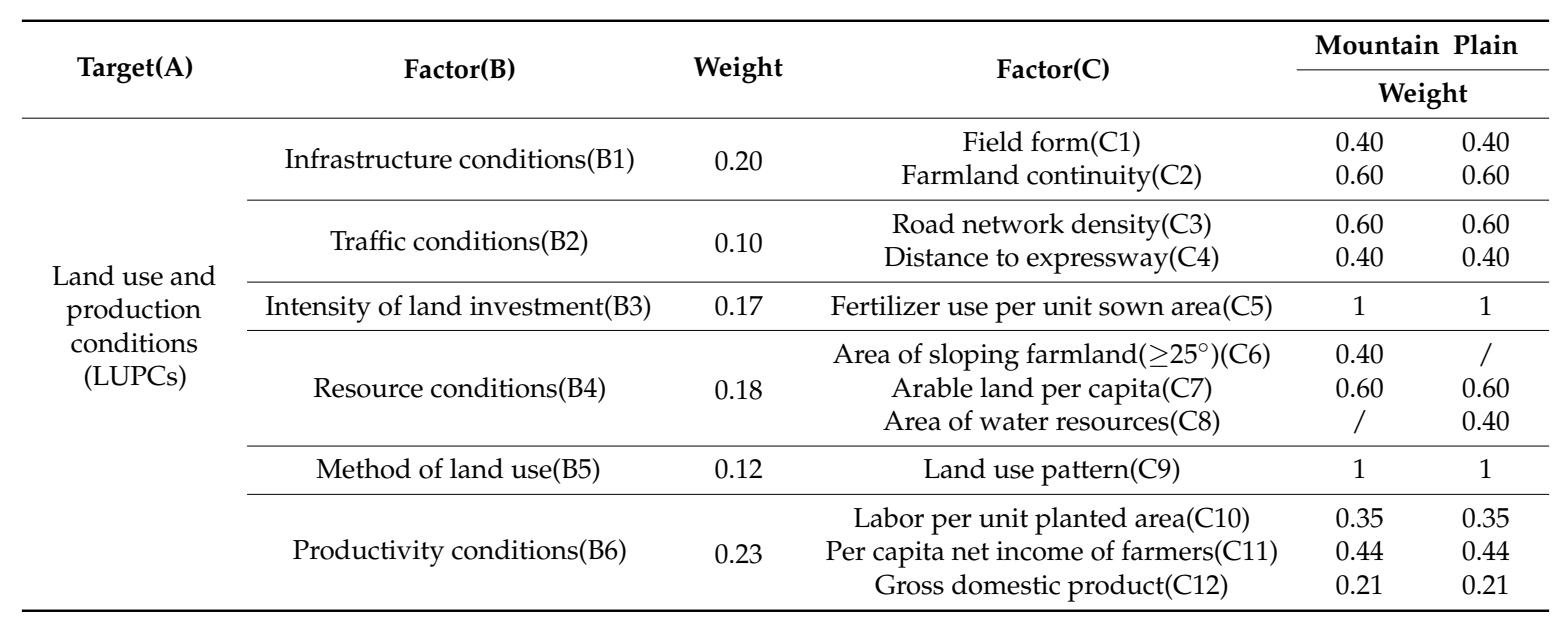

The CLQ evaluation indicators and scoring rules used in assessing UCL are shown in Table 2. The scores are determined by Natural breakpoint method to standardize the factor values and assign different grades, which are implemented by ArcGIS. Wei et al. [33] has used the method to divide the investment scale, construction scale, new cultivated land scale and number of projects into four categories [33].

Table 2. Introduction of index and grading rules.

\begin{tabular}{|c|c|c|c|}
\hline Index & Indicator Description & Range of Index Values & Score \\
\hline Plan form & $\begin{array}{l}\text { It affects the efficiency and convenience of cultivated land } \\
\text { use. The plan form (SHPE) can be calculated using the } \\
\text { perimeter }(C) \text { and area }(S) \text { of the plots; SHPE }=4 \sqrt{S} / C \text {. }\end{array}$ & $\begin{array}{l}{[0.79-1.2)} \\
(0.79-0.57] \\
{[0.34-0.57)} \\
\quad<0.34\end{array}$ & $\begin{array}{l}100 \\
80 \\
70 \\
60\end{array}$ \\
\hline Contiguity of plots & $\begin{array}{l}\text { Fields that are contiguous favor maximizing the use of } \\
\text { cultivated land and improve the efficiency of agricultural } \\
\text { facilities and economies of scale. The contiguity of plot } i \\
\left(P C_{i}\right) \text { can be calculated using the largest }\left(S_{\text {max }}\right) \text { and } \\
\text { smallest }\left(S_{\text {min }}\right) \text { plots within the study area and the field } \\
\text { area } S_{i} ; P C_{i}=\left(S_{\max }-S_{i}\right) /\left(S_{\max }-S_{i}\right)\end{array}$ & $\begin{array}{l}(0.87-1.14] \\
(0.67-0.87) \\
(0.44-0.67) \\
\quad<0.44\end{array}$ & $\begin{array}{l}100 \\
80 \\
70 \\
60\end{array}$ \\
\hline $\begin{array}{l}\text { Farmland road } \\
\text { network density } \\
\quad\left(\mathrm{km} / \mathrm{km}^{2}\right)\end{array}$ & $\begin{array}{l}\text { The area of cultivated land communication is mainly } \\
\text { affected by farmland road networks. Using the } \\
\text { administrative village as the statistical unit, the farmland } \\
\text { road network density = farmland road } \\
\text { length/administrative village land area. }\end{array}$ & $\begin{array}{l}\geq 3.17 \\
{[1.84-3.17)} \\
{[1.01-1.84)} \\
(0.29-1.01) \\
\quad<0.29\end{array}$ & $\begin{array}{l}100 \\
80 \\
70 \\
60 \\
40\end{array}$ \\
\hline $\begin{array}{c}\text { Distance to } \\
\text { expressway }(\mathrm{m})\end{array}$ & $\begin{array}{l}\text { Generally, the agricultural production of the area which is } \\
\text { adjacent within a certain range of expressway entrances or } \\
\text { exits has a relatively high degree of accessibility. The } \\
\text { negative impacts of expressways without access and } \\
\text { under improper operation and management on the land } \\
\text { use of the neighboring areas are relatively obvious. }\end{array}$ & $\begin{array}{l}\geq 4000 \\
{[1700-4000)} \\
(500-1700) \\
\quad<500\end{array}$ & $\begin{array}{l}100 \\
80 \\
70 \\
60\end{array}$ \\
\hline Land use pattern & $\begin{array}{c}\text { Refer to the "Second National Land Survey } \\
\text { Technical Regulation". }\end{array}$ & $\begin{array}{l}\text { Paddy fields } \\
\text { Irrigated land } \\
\quad \text { dry land }\end{array}$ & $\begin{array}{c}100 \\
80 \\
60\end{array}$ \\
\hline
\end{tabular}


Table 2. Cont.

\begin{tabular}{|c|c|c|c|}
\hline Index & Indicator Description & Range of Index Values & Score \\
\hline Water area (ha) & $\begin{array}{l}\text { The area of water resources, including rivers, lakes, } \\
\text { reservoirs, ponds, ditches, inland or coastal glaciers, and } \\
\text { glaciers and permanent snow cover. }\end{array}$ & $\begin{array}{l}\geq 360 \\
{[180-360)} \\
{[73-180)} \\
(18-73) \\
<18\end{array}$ & $\begin{array}{l}100 \\
90 \\
80 \\
60 \\
40\end{array}$ \\
\hline $\begin{array}{l}\text { Area of sloping } \\
\text { farmland (ha) }\end{array}$ & The area of cultivated land with a slope of $\geq 25^{\circ}$. & $\begin{array}{l}\geq 620 \\
{[290-620)} \\
{[120-290)} \\
{[40-120)} \\
\quad<40 \\
\quad=0\end{array}$ & $\begin{array}{c}20 \\
40 \\
60 \\
80 \\
90 \\
100\end{array}$ \\
\hline $\begin{array}{l}\text { Number of people in } \\
\text { the labor force per unit } \\
\text { of planted area } \\
\text { (person } / \mathrm{mu})\end{array}$ & $\begin{array}{l}\text { The labor input per unit area of cultivated land affects the } \\
\text { degree of maturity. The calculation of this index is based } \\
\text { on administrative villages, using statistical data. }\end{array}$ & $\begin{array}{c}\geq 1.3 \\
{[0.8-1.3)} \\
{[0.2-0.8)} \\
<0.2\end{array}$ & $\begin{array}{c}100 \\
80 \\
60 \\
40\end{array}$ \\
\hline $\begin{array}{l}\text { Fertilizer use per unit } \\
\text { sown area }(\mathrm{kg} / \mathrm{mu})\end{array}$ & $\begin{array}{l}\text { Using large quantities of fertilizer leads to soil pollution } \\
\text { and other problems, resulting in a decline in the quality of } \\
\text { cultivated land. The calculation of this index is based on } \\
\text { administrative villages, using data from the Statistical } \\
\text { Yearbook and the Agricultural Statistics Report. }\end{array}$ & $\begin{array}{c}<30 \\
{[30-60)} \\
{[60-80)} \\
\geq 80\end{array}$ & $\begin{array}{l}100 \\
80 \\
60 \\
40\end{array}$ \\
\hline $\begin{array}{l}\text { Per capita net income } \\
\text { of farmers (Yuan) }\end{array}$ & $\begin{array}{c}\text { The calculation of this index is based on administrative } \\
\text { villages and statistical data. }\end{array}$ & $\begin{array}{l}\geq 13,000 \\
{[10,000-13,000)} \\
{[7000-10,000)} \\
\quad<7000\end{array}$ & $\begin{array}{l}100 \\
80 \\
60 \\
40\end{array}$ \\
\hline $\begin{array}{l}\text { Per capita cultivated } \\
\text { land (mu/person) }\end{array}$ & $\begin{array}{c}\text { The total area of cultivated land divided by the total } \\
\text { population. }\end{array}$ & $\begin{array}{l}\geq 1.2 \\
{[0.7-1.2)} \\
{[0.18-0.7)} \\
<0.18\end{array}$ & $\begin{array}{l}100 \\
80 \\
60 \\
40\end{array}$ \\
\hline $\begin{array}{l}\text { Gross domestic } \\
\text { product (million Yuan) }\end{array}$ & $\begin{array}{l}\text { "GDP" means the market value of all final products and } \\
\text { services produced by all resident units in a country or } \\
\text { region for a specified period of time, and it can be } \\
\text { obtained by referring to the local Statistical Yearbook. }\end{array}$ & $\begin{array}{c}\geq 300,000 \\
{[150,000-300,000)} \\
{[50,000-150,000)} \\
<50,000\end{array}$ & $\begin{array}{c}100 \\
80 \\
60 \\
40\end{array}$ \\
\hline
\end{tabular}

\subsection{Determination of Monitoring Units and Soil Sampling}

The monitoring units are the basic unit used in the evaluation of UCL management activities. They represent the most detailed means of assessing the effects of UCL management mode on the CLQ. The monitoring unit is composed of fixed and random monitoring units. A fixed monitoring unit (FMU) is a representative unit in the area of UCL that is used to perform monitoring every year. FMUs should be laid out such that they are concentrated within areas of cultivated land, away from roads and cities. They can reflect the features of regional physical geography and agricultural production. In selecting FMUs, priority is given to standard farmland and high-quality basic farmland. Within the area contained by the FMU, a plurality of grading units is selected as the random monitoring unit. The property of the FMU is the average value of the attributes of the FMU and the matched random monitoring unit.

Soil sampling is required for each FMU. The scheme for sampling sites was designed to capture the landscape position, variability of landforms, and land uses within the catchment [34].The area of the sampling units ranged between 80 and $100 \mathrm{~m}^{2}$. From each sampling unit, 8 to 10 composite soil samples were collected randomly. The size and homogeneity (hydrologic conditions) of the sampling unit determined the number of composite samples [35]. Soil samples were collected at a depth of $20 \mathrm{~cm}$ because most changes that are expected to occur at this depth due to long-term land use management practices [35]. Subsequently, the soil samples were analyzed. The inspected indicators included soil $\mathrm{pH}$ and organic matter content. 


\subsection{Modification of the Grading of Cultivated Land Use}

On the basis of the physical quality grade index, we modified the land use quality grade index and adopted the same method as GALQ to re-divide the grade of CLQ [30]. The land use modification coefficient of each evaluation unit can be converted using the basis data obtained from the annual scores for 2009 and 2014. In the future, when more data are available, it would be better to use data that cover a longer time period to calculate the coefficients. The land use value $(F)$ of each unit can be calculated using a weighted average model (Equation (4)).

$$
\begin{gathered}
K_{p}=\sum_{i=1}^{f} A_{i} B_{i} \\
K_{p}^{\prime}=\sum_{i=1}^{f}\left(A_{i} B_{i}\right) \\
C_{p}=\frac{K_{p}}{K_{p}^{\prime}} \\
F=\sum_{i=1}^{2} W_{B, i} \sum_{j=1}^{n} W_{i j} F_{i j}
\end{gathered}
$$

In Equations (1)-(3), $K_{p}$ and $K_{p}{ }^{\prime}$ are the total cultivated land use value of the years 2014 and 2009 (the first phase of the results of the Second Land Survey of Hubei Province), respectively; $C_{p}$ is the correction coefficient for cultivated land use; $A i$ and $A i^{\prime}$ represent the supplemented values of the LUPC indicators for the years 2014 and 2009; and $B_{i}$ represents the weights associated with the LUPC indicators.

In Equation (4), $W_{B, i}$ is the weight of factor $i ; W_{i j}$ and $F_{i j}$ are the weight and score of factor $j$ under a given level of factor $i$; and $n$ is the number of factors, given the level of the corresponding factors.

\section{Application of the Evaluation System}

\subsection{Study Area}

The study area includes the south-central plain division (SCPDHP) and the southwest mountainous division of Hubei Province (SWMDHP) in China (Figure 2). These are as were chosen because they display contrasting biophysical, topographic and socioeconomic conditions [36] (Figure 3), which are representative of the cultivated land system in Hubei Province and most parts of China. The SCPDHP is an area of intensive agriculture with inherently humic top soils, high rainfall and substantial socioeconomic opportunities and population density [36]. In contrast, the SWMDHP displays lower agricultural potential, poor soils, lower socioeconomic opportunities and a sparser population distribution.

The SCPDHP is located in the middle reaches of the Yangtze River and is a typical alluvial lacustrine plain. It mainly includes most of the Jianghan Plain and covers 15 counties, districts or County-level cities including Jingzhou and other cities. The zonal soil is yellow-brown soil, the terrain is flat, the lake is densely covered, and the river network is interwoven. The region experiences favorable temperatures and rainfall conditions, and the CLQ is higher than that of other regions in China. It is greatly affected by the development of urbanization since it is located in the hinterland of the metropolitan area of Wuhan, and it faces the dilemma of economic development and farmland protection [37]. According to the Statistical Yearbook of Hubei Province, the urbanization rate of the Jianghan Plain increased from 9.52\% in 1980 to approximately $43.89 \%$ in 2010, and the area of cultivated land decreased by approximately $15.29 \%$ [37]. 


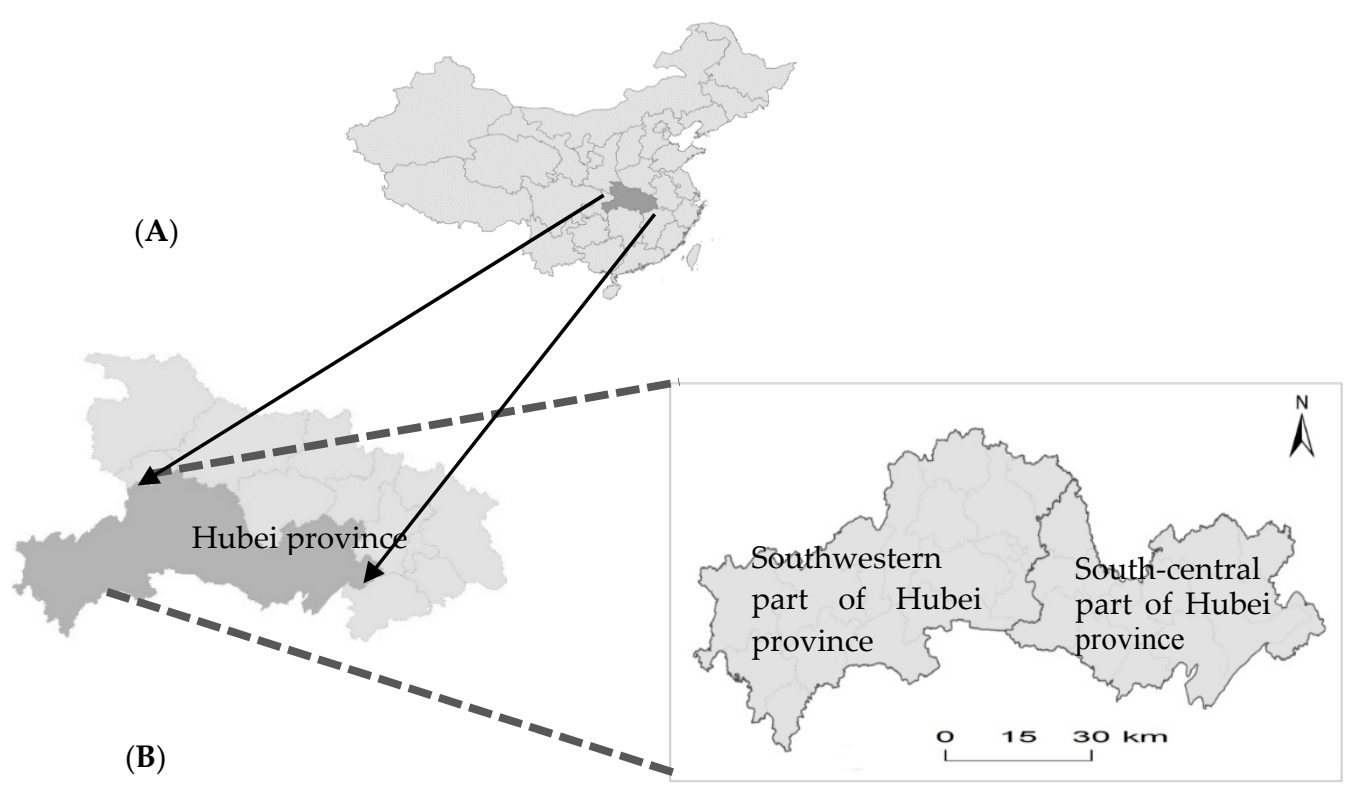

Figure 2. General situation of the study area: (A) the location of Hubei Province in China; and (B) area map of the south-central plain division and southwest mountainous division.

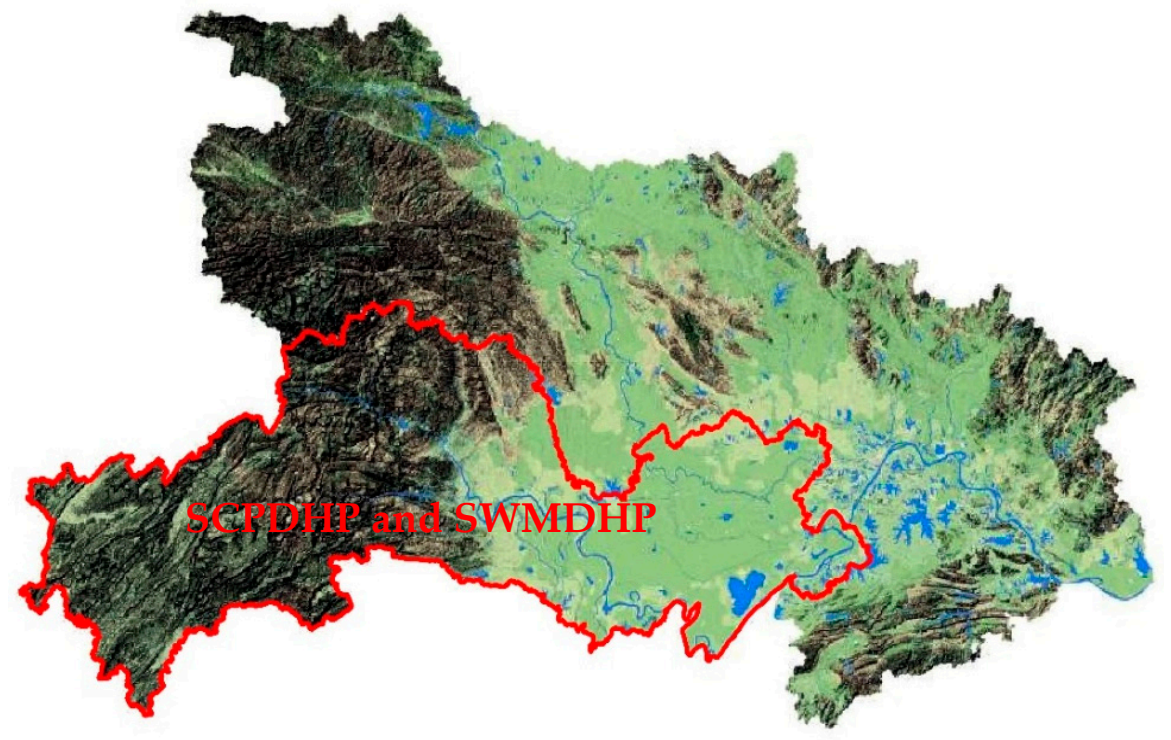

Figure 3. Topographic map of the study area.

The SWMDHP is located in the northeastern part of the Wuling Mountains in south-central China, and it represents the second ladder to the transition zone of the third ladder [38]. It contains 19 counties, districts or County-level cities of Enshi and Yichang City. The landscape of the area is generally rugged, and the altitude [35] ranges from 800 to $1000 \mathrm{~m}$ above sea level. The land use is predominantly agricultural and is planted with crops; however, the percentages of cover with trees, orchards, and tea vary. The major soil types are mountain yellow soil and mountain yellow-brown soil [39]. Conditions within the study area are warm in winter and cool in summer, the amount and distribution of rainfall are predictable, and the annual precipitation ranges [40] from 1100 to $1800 \mathrm{~mm}$ [39]. The geographical and climatic conditions differ from those of other regions that are representative of the central and southern mountainous areas of China [41].The region contains a national-level concentration of contiguous poor areas and a high number of poverty-stricken counties. In addition, the level of agricultural 
mechanization is low and traffic conditions are relatively backward within the region. These factors influence the relationship between environmental changes and household behaviors [42].

\subsection{Data Collection and Processing}

\subsubsection{Data Collection}

The data used in this study are mainly derived from the "Investigation and Evaluation of Cultivated Land Quality in Hubei Province" project, which was conducted in 2014 by the Department of Land and Resources of Hubei Province. This project provided results for a range of UCL in the study area, including CLQ grades, natural quality factor values, monitoring unit locations and attributes, and crop yields; however, the LUPCs are not provided. Additional investigations need to be carried out.

The supplemental survey data regarding this project can be obtained from two major sources, specifically the regional Statistical Yearbooks and land use change survey (LUCS) maps. The regional Statistical Yearbooks provide aggregated data for different administrative units which were collected by individual counties [43]. The datasets provide time series of actual data including indicators, such as population, the area of cultivated land, the amount of fertilizer applied, the number of people in the labor force, and the net income of farmers. The limitations of such data include the relatively coarse size of the administrative units and the methods of data collection used in different counties [43]. In contrast, it's more easily applied consistently for the methods been used to derive LUCS map sources, and these maps provide greater spatial detail [43]. These data may represent an important first step in improving our understanding of the spatial distribution of LUPCs within the study area.

\subsubsection{Data Processing}

Delineate the Scope of Evaluation

Using the method of spatial super position built into GIS software, based on the map of the LUCS database in 2014, we cut out the following two parts to determine the scope of the UCL.

- The newly increased cultivated land.

This quantity includes two parts. One part represents the supplementary cultivated land due to land consolidation, whereas the other represents increases that have occurred within the past three years that were caused by the self-development of farmers, adjustments in the agricultural structure or other causes. Newly cultivated land areas can be extracted according to the results of the LUCS map covering nearly three years. The scope of the project area and the final materials shall be subject to approval.

- Reductions in cultivated land.

In the past three years, the area of cultivated land has decreased due to construction, disasters, adjustment in agricultural structure and ecological restoration. According to the LUCS map results for 2012 and 2014, the reductions in cultivated land areas are extracted.

Finally, the attribute data of the updated evaluation units for 2013are transferred into the cultivated land units in 2014 using GIS software (Figure 4). 


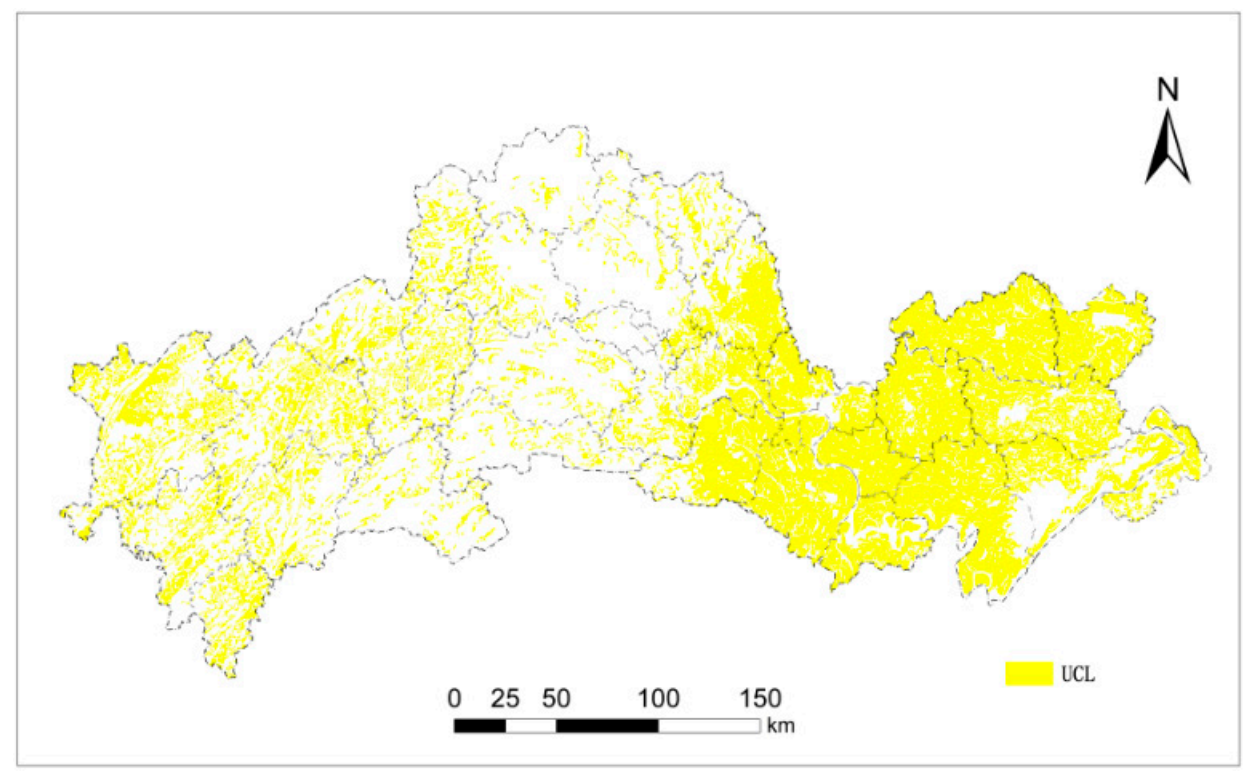

Figure 4. Spatial distribution of UCL.

Acquisition of Evaluation Index Value

According to the supplementary land use evaluation index (Table 1), the area of cultivated land per capita (C7), GDP (C12) and other indicators (C5, C10, and C11) can be obtained from the Statistical Yearbook, and field form (C1), farmland continuity (C2), road network density (C3) and the other four indexes (C4, C6, C8 and C9) can be derived using the analysis tools with in the ArcGIS software package, including overlay analysis, extraction analysis and field analysis. The distance and area to the nearest neighbor can be calculated using the spatial statistics tool. In this paper, the research unit includes 34 counties, districts or County-level cities within the study area. Ultimately, factor values were obtained for 34 counties using data from 747 FMUs (Figure 5).

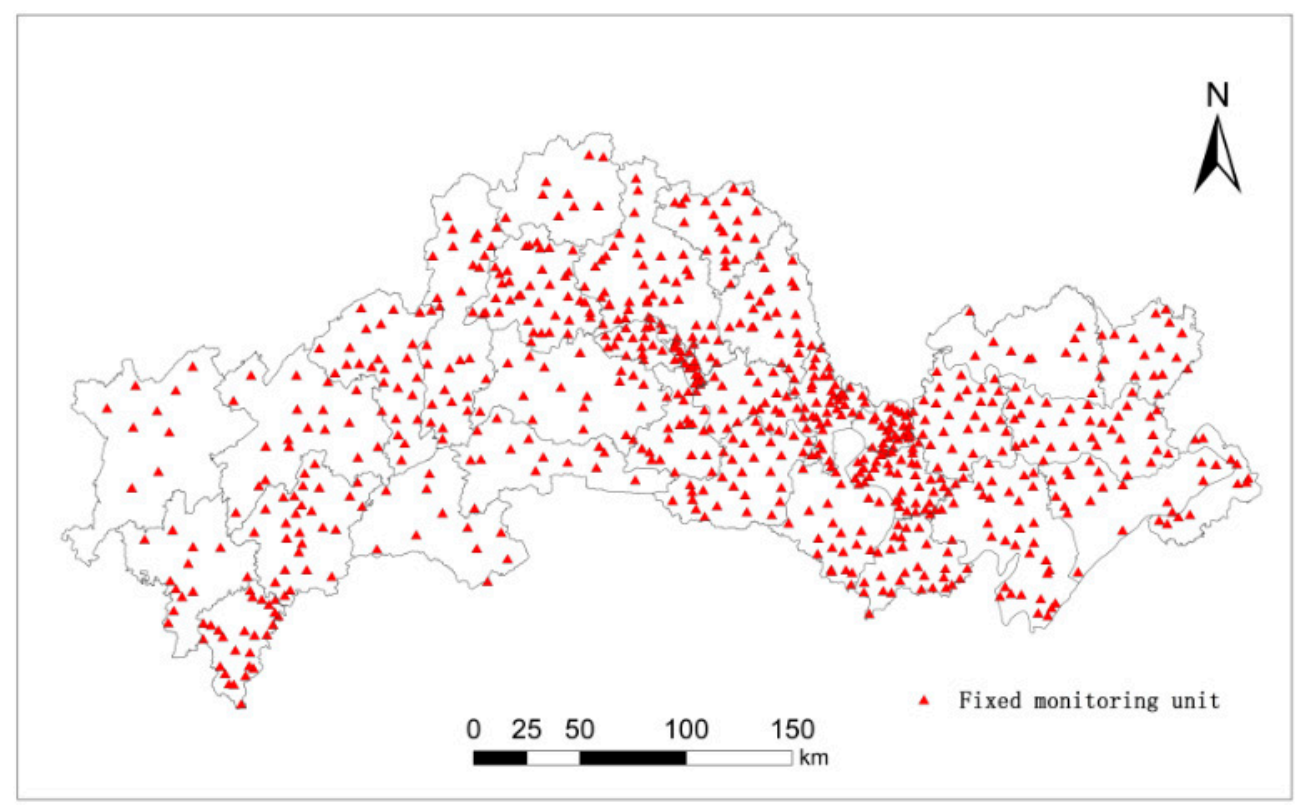

Figure 5. Spatial distribution of fixed monitoring units (FMUs). 


\subsection{Results and Discussion}

\subsubsection{Basic Characteristics of CLQ within the Study Area}

According to the GALQ results for China issued by the Ministry of Land and Resources in December 2009, the agricultural land within China was divided into 15 categories (primarily categories 7-13).The mean classification calculated using area weighted averaging (CC-AWA) was 9.8 [44]. Assessment of the study area showed that the grades of CLQ present within the study area in 2014 were 5-9 and the CC-AWA was 7.6, which indicates that the overall level of CLQ in the study area was moderate and slightly higher than the national average. Among the 34 counties of the SCPDHP and the SWMDHP, the counties with the three best overall optimal average classifications are Zigui and Xiaoting within the SWMDHP and Gongan within the SCPDHP, which have values of 2.9, 4.1 and 4.5, respectively. The three counties with the worst average classification values areLaifeng, Enshi and Badong within the SWMDHP, which have values of 12.6, 13 and 13.1, respectively. Excellent and high-quality UCL occurs primarily within the SCPDHP. The lower part is mainly distributed within the SWMDHP (Figure 6).

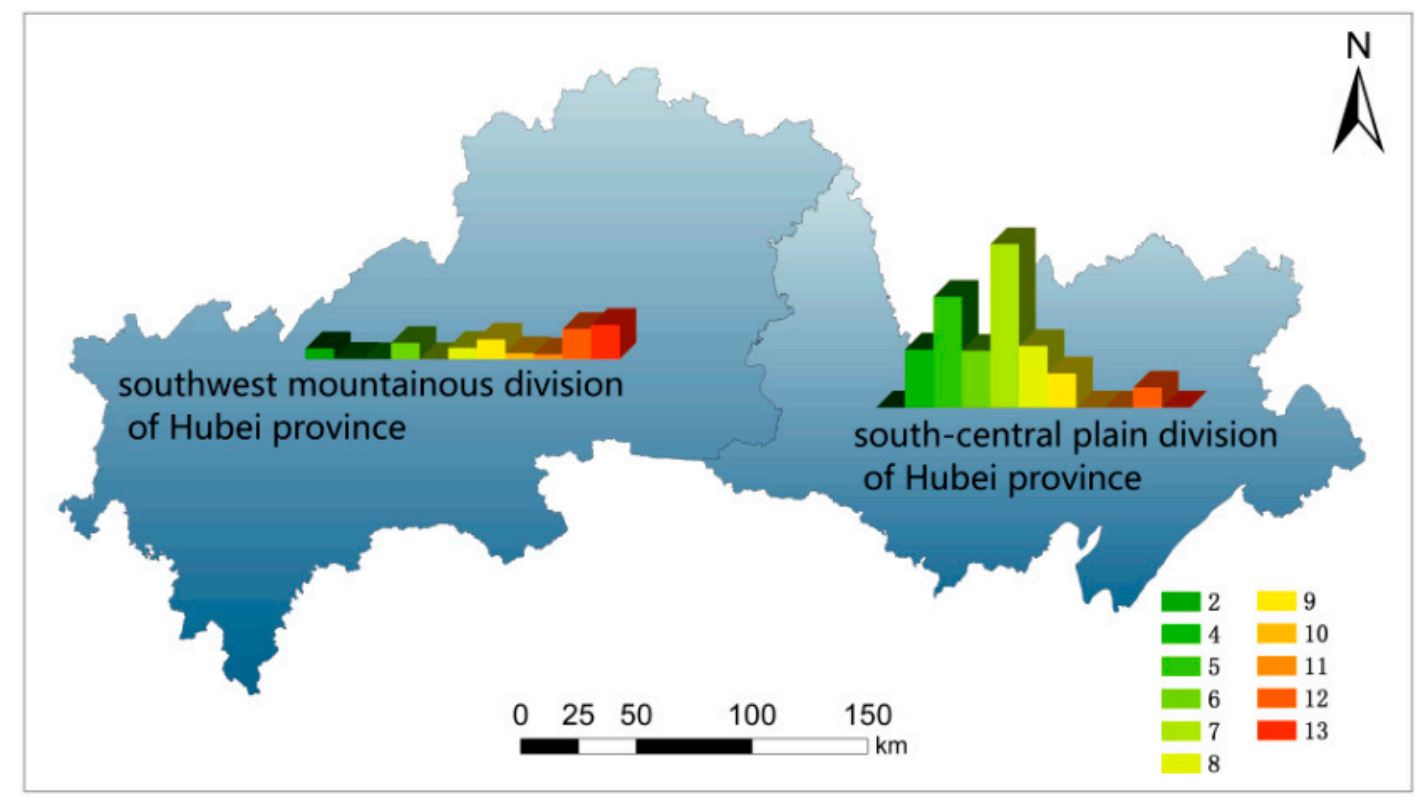

Figure 6. Comparison of the average quality grade of UCL within the study area.

The quality of cultivated land can be divided into four classes, based on their gradation: excellent (1-4), high (5-8), moderate (9-12) and low (13-15) [44]. The area covered by cultivated land with the excellent grade is $968.0 \mathrm{kha}$, which accounts for $14.9 \%$ of the total area; the high grade is inferred for $3589.5 \mathrm{kha}$, which accounts for $55.3 \%$ of the total area; and the areas of the moderate and low grades are $1648.8 \mathrm{kha}$ and $285.0 \mathrm{kha}$, and these grades account for $25.4 \%$ and $4.4 \%$ of the total area, respectively. The statistics of the four classes of cultivated land at the County level (Figures 7 and 8, and Table 3) reveal that the structure of the gradation differs among the counties within the study area.

Figure 7 compares the calculation results from the conventional GALQ method (without using socioeconomic factors) and the proposed CAF approach. Apparently, GALQ would overestimate the land quality, where part of the cultivated land grades (CLG) of SCPDHP are in the range of excellent (1-4), which fall into the moderate quality range (5-8) in the CAF evaluation. On the other aspect, the CLG of SWMDHP in the low range (13-15) derived from CAF is much wider than that from GALQ. Consequently, the integration of the land use evaluation factors and correction coefficient should be more comprehensive to reflect the impact of land use conditions of CLQ. 
Table 3. Structure of the grade of cultivated land of the 34 counties in the study area.

\begin{tabular}{|c|c|c|c|c|c|c|c|c|c|}
\hline County (District, City) & $\begin{array}{c}\text { Excellent } \\
\text { (kha) }\end{array}$ & $\begin{array}{l}\text { High } \\
\text { (kha) }\end{array}$ & $\begin{array}{c}\text { Moderate } \\
\text { (kha) }\end{array}$ & Low (kha) & County (District, City) & $\begin{array}{c}\text { Excellent } \\
\text { (kha) }\end{array}$ & $\begin{array}{l}\text { High } \\
\text { (kha) }\end{array}$ & $\begin{array}{c}\text { Moderate } \\
\text { (kha) }\end{array}$ & $\begin{array}{r}\text { Low } \\
\text { (kha) }\end{array}$ \\
\hline Lichuan & - & 0.1 & 110.8 & - & Dangyang & - & 0.0 & 180.4 & 22.0 \\
\hline Xianfeng & - & - & 47.7 & - & Zhijiang & - & 142.4 & 49.8 & - \\
\hline Laifeng & - & - & 42.2 & 34.7 & Songzi & 14.8 & 239.0 & 0.1 & - \\
\hline Xuanen & - & 22.1 & 98.3 & - & Shashi & 4.3 & 71.2 & - & - \\
\hline Enshi & - & - & 66.5 & 68.8 & Jingzhou & 89.2 & 379.2 & - & - \\
\hline Jianshi & 31.8 & 120.2 & 13.3 & - & Jianglin & 263.5 & 206.9 & - & - \\
\hline Hefeng & - & - & 14.8 & 7.8 & Gongan & 82.9 & 36.9 & - & - \\
\hline Badong & - & - & 75.6 & 138.7 & Jianli & - & 388.3 & 238.3 & - \\
\hline Wufeng & - & - & 34.8 & 7.7 & Shishou & - & 129.5 & 218.0 & - \\
\hline Changyang & - & - & 48.1 & 5.3 & Honghu & - & 51.8 & 13.9 & - \\
\hline Xiling & - & 0.0 & 0.1 & - & Qianjiang & 115.3 & 644.9 & 222.7 & - \\
\hline Dianjun & - & 1.0 & 5.0 & - & Xiantao & 173.1 & 750.5 & 15.9 & - \\
\hline Xiaoting & 2.2 & 1.8 & - & - & Tianmen & 96.6 & 92.0 & - & - \\
\hline Wujiagang & - & 0.1 & 0.1 & - & Hanchuan & 2.5 & 154.9 & 10.9 & - \\
\hline Yiling & - & 65.6 & 32.3 & - & Jiayu & - & 33.5 & - & - \\
\hline Zigui & 91.9 & 18.1 & - & - & Subtotal for the SCPDHP & 842.1 & 3320.7 & 949.9 & 22.0 \\
\hline Yuanan & - & 18.6 & 60.2 & - & Total & 968.0 & 3589.5 & 1648.8 & 285.0 \\
\hline Xingshan & - & 11.9 & 6.1 & - & & & & & \\
\hline Yidu & - & 9.5 & 43.7 & - & & & & & \\
\hline Subtotal for the SWMDHP & 125.9 & 268.8 & 699.0 & 263.0 & & & & & \\
\hline
\end{tabular}




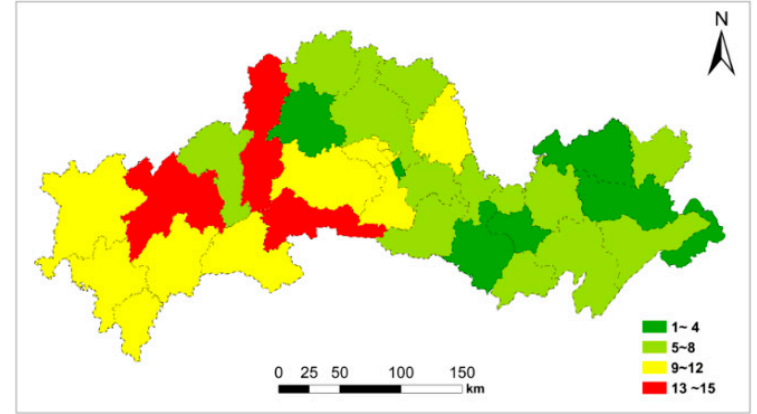

(A)

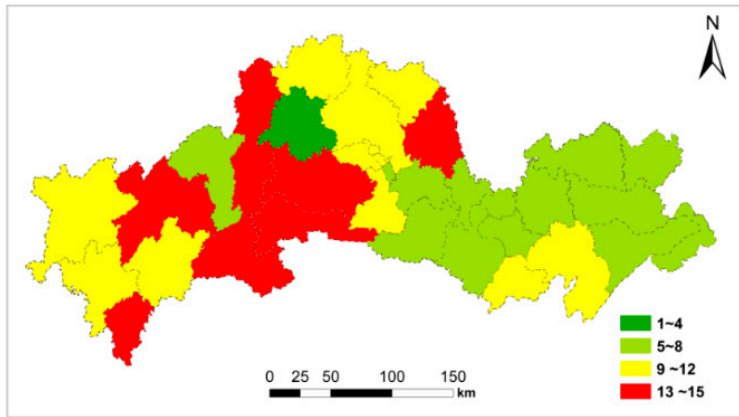

(B)

Figure 7. Spatial distribution of UCL grade in 2014: (A) result of GALQ; and (B) result of CAF.

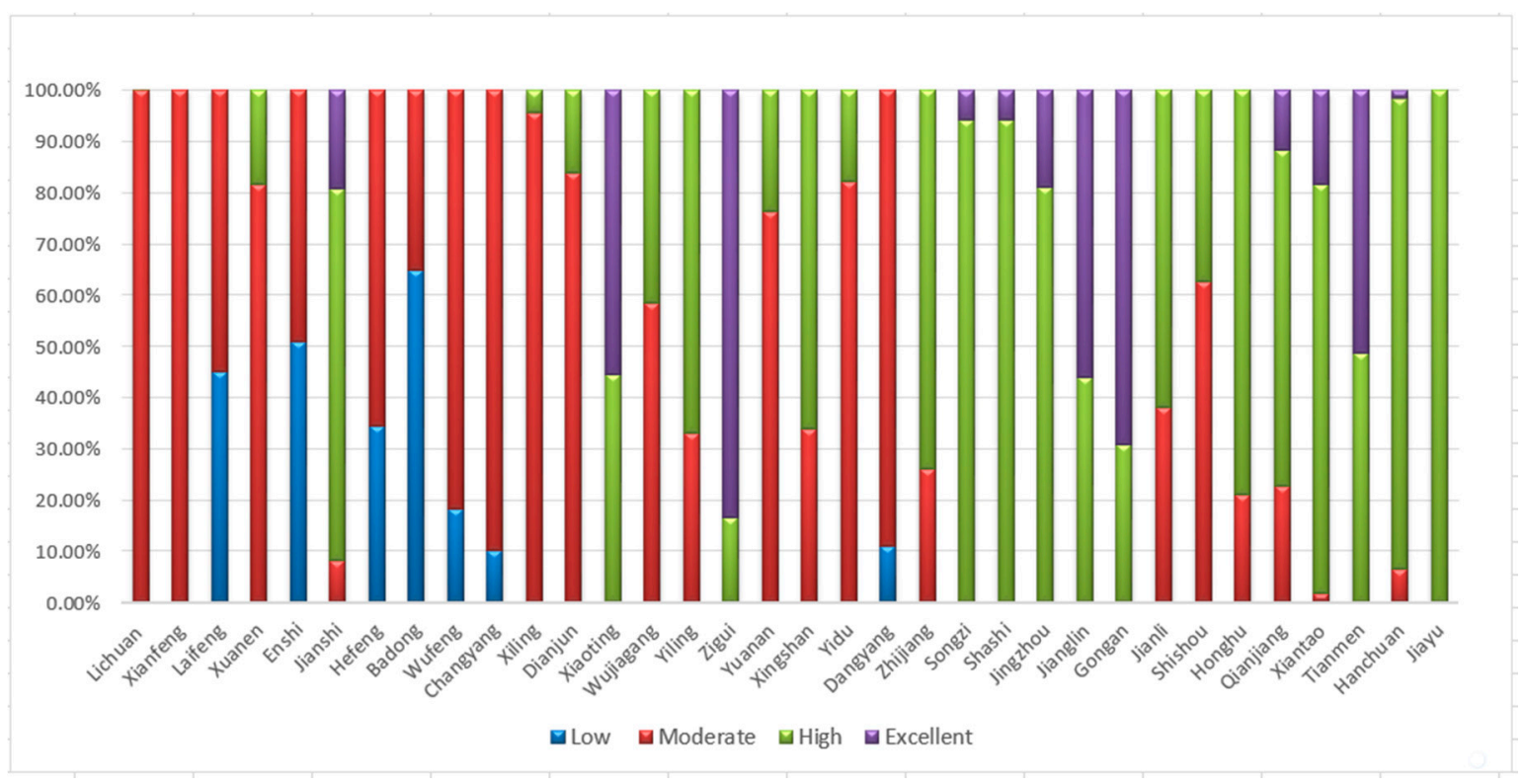

Figure 8. Structure of the grade of cultivated land ofthe 34 counties.

The Excellent and High Grades Are Mainly Located in the SCPDHP

The top $87.0 \%$ of cultivated land is distributed in the SCPDHP, and the excellent grade is only found in Jianshi County, Xiaoting District and Zigui County of SWMDHP. There are fifteen counties in the SCPDHP, of which nine contain excellent cultivated land (grades 1-4). However, the total area of excellent cultivated land is small. Only the three counties of Jiangling, Qianjiang and Xiantao contain areas of excellent cultivated land larger than 100 kha. Jingzhou District, Gongan County and Tianmen are three counties with areas of excellent cultivated land of 80 to $100 \mathrm{kha}$, whereas the area of excellent cultivated land in Songzi is $15 \mathrm{kha}$, and the remaining Shashi District and Hanchuan contain areas of excellent cultivated land that are less than 5 kha in size.

Meanwhile, $92.5 \%$ of the high grade cultivated land (grades 5-8) is distributed in the SCPDHP, with a large area of $3320.7 \mathrm{kha}$. The areas ofhigh grade cultivated land in Xiantao and Qianjiang County are greater than $600 \mathrm{kha}$, whereas the areas of high grade cultivated land in the 4 counties of Jianli, Jingzhou, Songzi and Jiangling are more than $200 \mathrm{kha}$. The areas of high grade cultivated land in the other counties all fall within the range of 30-60 kha, with the exception of Dangyang, which does not contain high-grade cultivated land. Although high grade cultivated land occursin $58 \%$ of the counties in the SWMDHP, the areas are small. The exceptions include Jianshi County and Yiling 
District, which contain more than 100 kha and more than 50 kha of high grade cultivated land. The other counties include less than 30 kha of high grade cultivated land.

Moderate Grade Cultivated Land Is Distributed Widely, and Low Grade Cultivated Land Is Mainly Distributed in the SWMDHP

The land assessment shows that $42.4 \%$ of the moderate grade cultivated land is found within the SWMDHP, whereas $57.6 \%$ is found within the SCPDHP. However, the distribution is relatively balanced in the SWMDHP, and the moderate grade cultivated land is found in most of the 17 counties except Xiaoting District and Zigui County. Among the 17 counties, the largest area is $110.8 \mathrm{kha}$, and the average size is $36.8 \mathrm{kha}$. The moderate grade cultivated landis more concentrated in the SCPDHP. Moderate grade cultivated land is distributed in nine counties in the SCPDHP, including Dangyang City, Jianli County, Shishou City and Qianjiang City, which contain areas of moderate grade cultivated land greater than $180 \mathrm{kha}$. Within these counties, the maximum area of moderate grade cultivated land is $238.3 \mathrm{kha}$, and the average area of moderate grade cultivated land is $63.3 \mathrm{kha}$.

$92.3 \%$ of the low grade cultivated land occurs within the SWMDHP. The area of low grade cultivated land within Badong Countyis more than $100 \mathrm{kha}$, whereas the corresponding areas within Enshi City and Laifeng County are 30-70 kha. The areas of low grade cultivated land within the remaining three counties are 5-10 kha. In the SCPDHP, low grade cultivated land is found only in Dangyang City, which is bounded to the east by the SWMDHP.

The Distribution of the Different Grades of Cultivated Land across Counties and within Individual Counties

The distribution of the different grades of cultivated land across counties and within individual counties is complex (Figure 9). First, the degree of concentration of cultivated land differs among the counties, which is reflected in the difference between the best and worst monitoring units found in each of the counties. For example, in the counties of the SWMDHP, such as Jianshi and Xiaoting, and in the counties of the SCPDHP, such as Qianjiang and Xiantao, the gap between the highest and the lowest monitoring units is more than seven on average, compared to less than three for Badong County in the SWMDHP and Shishou City and Jiayu County in the SCPDHP. For the SCPDHP, the gap between the highest and the lowest monitoring units is slightly larger than that of the SWMDHP, and these gaps are 4.9 and 4.5, respectively. Second, the deviation of the average quality grade between the counties and the study area is quite different. For instance, counties such as Laifeng, Enshi, and Badong in the SWMDHP are five grades lower than the average level for the study area (AL-SA). In contrast, Gongan County in the SCPDHP is three grades higher than the AL-SA. Generally, the CLQ in the SCPDHP is better than that of the regional average, whereas those in the SWMDHP are lower than the regional average. Third, the deviation of the average grade of the counties is different from that within the counties. For example, the average grade is one higher than the mean grade for Tianmen City, while the average grade is $0.3-0.5$ lower than the mean grade for Zhijiang City and Gongan County. This result shows that greater deviations between the average and mean grades were noted in the SCPDHP, and the width of the distribution in the SCPDHP is greater than that in the SWMDHP. This variability could be owing to spatial differences in the natural processes that have shaped the landscape, as well as land management practices [4]. 


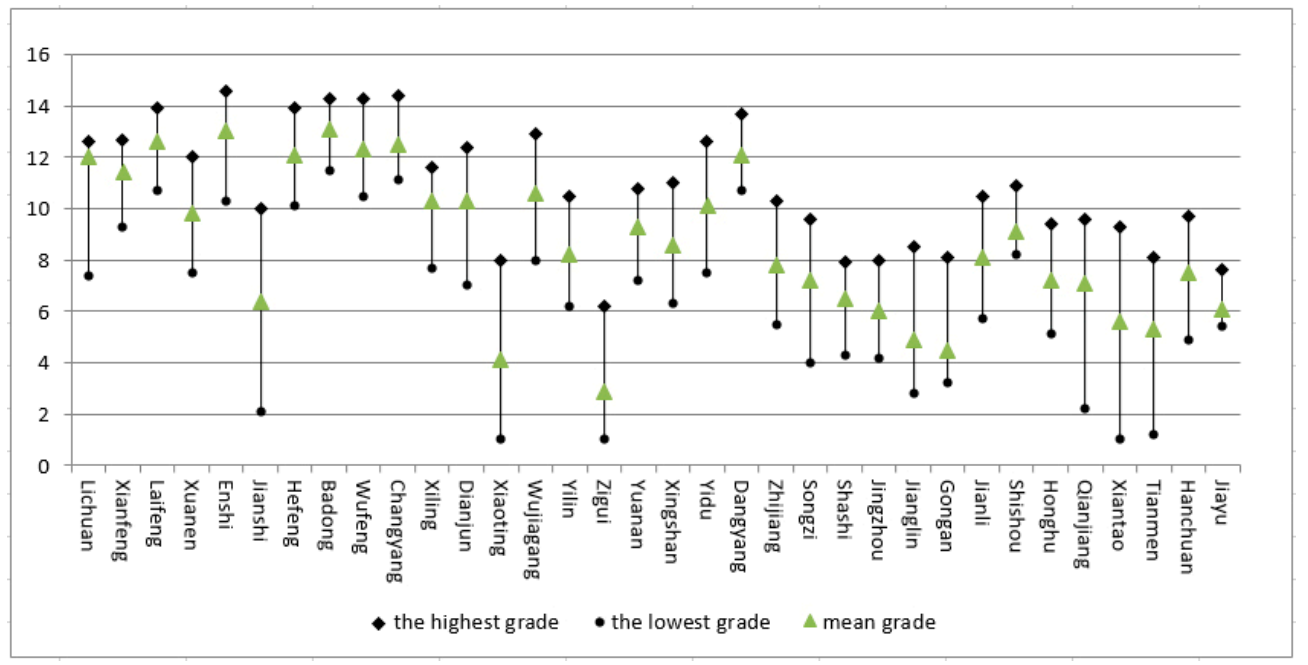

Figure 9. The highest, lowest and average grades of UCL quality in the counties within the study area.

\subsubsection{Variation in LUPCs across the Study Area}

Values of several descriptive statistics, specifically the mean, maximum, minimum, standard deviation (SD), coefficient of variation (CV) and skew ness, were calculated for measuring land properties [4]. The $\mathrm{CV}$ was calculated to enable understanding of the spatial variability of the land characteristics. Generally, land characteristics can be expressed by dividing the CV into different ranges [45]. E.g., a CV less than 10\% indicates minimal variability, a CV less than $100 \%$ indicates moderate variability, and a CV that exceeds $100 \%$ reflects intense variability [46].

Based on the County level, the CV of 12 land use factors were calculated using data collected at FMU sin the SCPDHP and SWMDHP (Tables 4 and 5). In total, 385 and 362 FMUs were set up in the SCPDHP and the SWMDHP, respectively. After eliminating the abnormal values of 0 that were obtained for some indexes, 336 values remained for the SCPDHP, whereas 337 values were retained for the SWMDHP.

There is obvious differences in the land properties between the SCPDHP and the SWMDHP. The SCPDHP displays higher values for $\mathrm{C} 1, \mathrm{C} 2, \mathrm{C} 3$, and $\mathrm{C} 5$ and most of the LUPCs compared to the SWMDHP. Using the CV to express variability [4], C8, C10 and C12 were the most variable $(\geq 100 \%)$ LUPCs for the SCPDHP. Moderate variability (CV 50-100\%) was observed for C4, C5 and C7, while $\mathrm{C} 1, \mathrm{C} 2, \mathrm{C} 3, \mathrm{C} 9$ and $\mathrm{C} 11$ displayed the least variability (CV < 50\%). For the SWMDHP, C4, C6, C8, C10 and $\mathrm{C} 12$ were the most variable LUPCs; $\mathrm{C} 3$ and $\mathrm{C} 7$ displayed moderate variability; and $\mathrm{C} 1, \mathrm{C} 2, \mathrm{C} 5, \mathrm{C} 9$ and $\mathrm{C} 11$ displayed minimal variability.

Table 4. Descriptive statistics for the LUPCs of the SCPDHP.

\begin{tabular}{ccccccc}
\hline LUPC & $\begin{array}{c}\text { Number of } \\
\text { Monitoring } \\
\text { Units }\end{array}$ & Minimum & Maximum & Mean & SD & CV\% \\
\hline Field form (C1) & 336 & 0.34 & 1.02 & 0.7746 & 0.16569 & 21.4 \\
Farmland continuity (C2) & 336 & 0.04 & 1.7500 & 0.8067 & 0.18686 & 23.2 \\
Road network density (C3) & 336 & 0.125 & 9.360 & 3.6010 & 1.634488 & 45.4 \\
Distance to expressway (C4) & 336 & 7.01 & 8730.47 & 1744.6 & 1.69001 & 96.9 \\
The amount of chemical fertilizer & 336 & 3.57 & 183.74 & 65.569 & 45.9596 & 70.1 \\
applied per unit sown area (C5) & 336 & 0.02 & 5.6000 & 1.7388 & 1.03307 & 59.4 \\
Cultivated land per capita (C7) & 336 & 0.80 & 1102.26 & 105.89 & 127.4116 & 120.3 \\
Area of water resources (C8) & 336 & 60.00 & 100.00 & 89.642 & 14.737 & 16.4 \\
Land use pattern (C9) & 336 & 0.004 & 1.1700 & 0.1270 & 0.13854 & 109.1 \\
Laborper unit planted area (C10) & 336 & 5650.00 & $20,119.00$ & $12,480.7$ & 1963.748 & 15.7 \\
Per capita net income of farmers (C11) & 336 & 8081.00 & $1,050,910.00$ & $203,294.54$ & 2.2874 & 112.5 \\
Gross domestic product (C12) & & & & & & \\
\hline
\end{tabular}


Table 5. Descriptive statistics for the LUPCs of the SWMDHP.

\begin{tabular}{ccccccc}
\hline LUPC & $\begin{array}{c}\text { Number of } \\
\text { Monitoring } \\
\text { Units }\end{array}$ & Minimum & Maximum & Mean & SD & CV\% \\
\hline Field form (C1) & 337 & 0.08 & 0.97 & 0.5339 & 0.18345 & 34.4 \\
Farmland continuity (C2) & 337 & 0.03 & 0.99 & 0.637122 & 0.246160 & 38.6 \\
Road network density (C3) & 337 & 0.06 & 11.27 & 2.17522 & 1.29476 & 59.5 \\
Distance to expressway (C4) & 337 & 5.7 & $37,230.14$ & 6400.183 & 8686.318 & 135.7 \\
The amount of chemical fertilizer & 337 & 5.08 & 103.26 & 36.1073 & 16.8964 & 46.8 \\
applied per unit sown area (C5) & 337 & 0 & 1550 & 203.5152 & 320.6862 & 157.6 \\
Area of sloping farmland( $\geq 25^{\circ}$ )(C6) & 337 & 0.04 & 3.33 & 1.25095 & 0.6601788 & 52.8 \\
Cultivated land per capita (C7) & 337 & 0.14 & 768.42 & 33.0436 & 69.73187 & 211.0 \\
Area of water resources (C8) & 337 & 60 & 100 & 79.5252 & 19.69439 & 24.8 \\
Land use pattern(C9) & 337 & 0.04 & 3.42 & 0.415252 & 0.6170586 & 148.6 \\
Labor per unit planted area (C10) & 337 & 6164 & 16,630 & 9849.3472 & 3231.588 & 32.8 \\
Per capita net income of farmers (C11) & 337 & 14,796 & $1,813,960$ & $205,795.10$ & 308,806 & 150.1 \\
Gross domestic product (C12) & & & & &
\end{tabular}

The data analysis presented in Tables 4 and 5 reveals that the CVs of the LUPCs in the SCPDHP range from 15.7 to $120.3 \%$, where as those of the SWMDHP range from 24.8 to $211.0 \%$. The CVs calculated for the two divisions all reflect intense and moderate variability, according to generally accepted standards. The greatest variability for the SCPDHP and the SWMDHP are observed for $\mathrm{C} 8, \mathrm{C} 10$ and $\mathrm{C} 12$, whereas the minimal variability for the two divisions are observed for $\mathrm{C} 1, \mathrm{C} 2, \mathrm{C} 9$ and $\mathrm{C} 11$. These results show that the infrastructure and traffic conditions and especially the resource conditions and economic development levels of the counties in each of the two districts are unbalanced. Moreover, the spatial differences in the CVs in the mountainous areas are clearly greater than that in the plain areas (Figure 10).

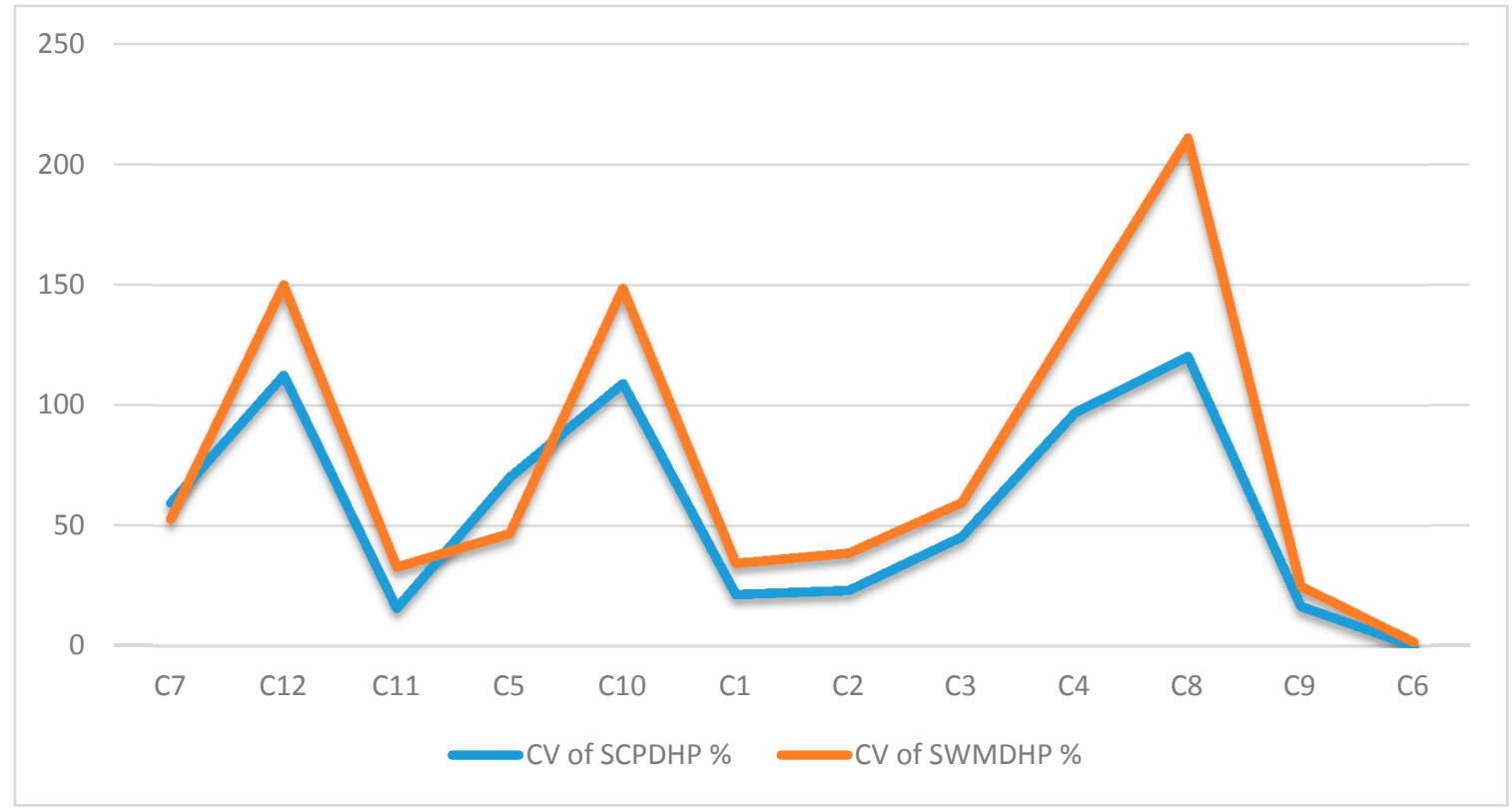

Figure 10. Comparison of the CV of the land use factors between the SCPDHP and the SWMDHP in 2014.

Owing to the very complicated nature of soil, which depends on its physical, chemical and biological properties and their interactions, the accuracy of soil quality assessment is increased by using as many indicators as possible [47]. This variability may be due to spatial differences in geographical location, as well as land management practices [4]. Different areas display different natural properties and management practices [48]. Momtaz et al. [48] and Seyfried et al. [49] observed 
that the distribution and variability of land properties depend on the scale- - the bigger the scale, the higher the variability, and vice versa [4]. For all that, the variability provided a better view of the status of the soil across the study area [4].

\subsubsection{Analysis of the Limiting Factors of the Comprehensive CLQ}

To facilitate the division of restricted types, the LUPCs were divided into categories that reflect utilization convenience (UC) (including C5, C7, C10, C11 and C12) and utilization stability (US) (including C1, C2, C3, C4, C6 or C8 and C9). Comparative analysis of the moderate (grades 9-12) and low (grades 13-15) grades of cultivated land for the natural quality and LUPC scores indicate that the comprehensive quality of the study area of UCL in terms of three single levels (natural quality, UC and US) and two combinatorial levels (natural and UC, natural and US) is limited. Of these levels, for the cultivated land (CL) that is limited by natural conditions, the comprehensive quality is mainly affected by organic matter, soil $\mathrm{pH}$ values and groundwater depth, as well as GDP and labor, while natural factors play a major role (Table 6). The CL that is limited by UC is affected by obstacle depth, the irrigation guarantee rate and $\mathrm{C} 1, \mathrm{C} 2, \mathrm{C} 4, \mathrm{C} 8$ and $\mathrm{C} 10$. The CL that is limited by US is substantially influenced by soil $\mathrm{pH}$, the irrigation guarantee rate and $\mathrm{C} 10, \mathrm{C} 11$ and $\mathrm{C} 12$. However, the two combinations of the restricted types of cultivated land are limited by different levels and factors. This interaction interprets the intricate relationship between improving soil fertility and LUPCs in the UCL area.

The variations observed across studies depend on specific soil-forming processes, land conditions and management-related factors [50]. Further analysis shows that groundwater depth, obstacle depth and profile configuration are affected by regional physical and geographical conditions, which are difficult to improve in the short term. Organic matter, soil $\mathrm{pH}$ and the irrigation guarantee rate should be improved as soon as possible through changing the fertilization methods used and carrying out land consolidated projects. The organic matter is too high in many counties, and the soil is acidic or alkaline, which shows that farmers depend on cultivated land excessively. Soil acidity or alkalinity can reduce yields by reducing phosphorus $(\mathrm{P})$ availability and increasing aluminum $(\mathrm{Al})$ and manganese $(\mathrm{Mn})$ toxicity [51,52]. The shortage of the labor force reflects the smallholder cropping systems [4] that have mainly been used by the labor force for a long time. It is an important factor affecting the comprehensive quality of CL. We find that private land use decisions depend critically on land quality and have been steered by anticipated economic returns to alternative uses, which in some cases have been affected significantly by public policies, sometimes intentionally and sometimes unintentionally [53]. There is strong evidence that the observed declines in croplands over the past two decades have been caused by falling crop net returns and the existence of the Conservation Reserve Program (CRP), as has been suggested by other research [54].

With the continuous progress of urbanization, rural labor is lost, and the degree of agriculture sideline operations is rising. In the existing land management system, situations such as land fragmentation by road networks and unstable management rights are difficult to change [27]. To protect basic crop yields and profits, the use of chemical fertilizers, pesticides and other chemical products and abandonment of cultivated land will likely increase, the land sustainable utilization will be under threat [27]. Despite this situation, the analysis of limiting factors further affirms the need for integrated sustainable land management (SLM) as a strategy to ensure nutrient availability and improve LUPCs. Efforts to enhance SLM should work on promoting the transfer of regional use rights of CL, advocating scale management and at the same time raising the level of agricultural mechanization. 
Table 6. Statistics of the main factors limiting the comprehensive quality of arable land.

\begin{tabular}{|c|c|c|c|c|c|c|c|c|c|}
\hline \multicolumn{10}{|c|}{ Natural Quality Limited Type } \\
\hline Involved Counties & Metric & $\begin{array}{l}\text { Organic } \\
\text { Matter }\end{array}$ & $\mathrm{pH}$ & $\begin{array}{c}\text { Irrigation } \\
\text { Guarantee Rate }\end{array}$ & $\begin{array}{l}\text { Groundwater } \\
\text { Depth }\end{array}$ & GDP & $\begin{array}{l}\text { Labor per Unit } \\
\text { Planted Area }\end{array}$ & Form Field & $\begin{array}{l}\text { Farmland } \\
\text { Continuity }\end{array}$ \\
\hline Zhijiang, Qianjiang, & Maximum & 100 & 90 & 100 & 100 & 100 & 60 & 100 & 100 \\
\hline Shishou, Jianli, & Minimum & 50 & 50 & 50 & 50 & 20 & 40 & 70 & 70 \\
\hline Honghu & Mean & 79.29 & 72.86 & 84.29 & 78.57 & 72.86 & 42.86 & 93.57 & 92.86 \\
\hline \multicolumn{10}{|c|}{ Use Convenience Limited Type } \\
\hline Involved Counties & Metric & $\begin{array}{c}\text { Profile } \\
\text { Configuration }\end{array}$ & $\mathrm{pH}$ & Obstacle Depth & $\begin{array}{c}\text { Irrigation } \\
\text { Guarantee Rate }\end{array}$ & GDP & $\begin{array}{l}\text { Labor per Unit } \\
\text { Planted Area }\end{array}$ & $\begin{array}{l}\text { Distance to } \\
\text { Expressway }\end{array}$ & $\begin{array}{c}\text { Water } \\
\text { Resources Area }\end{array}$ \\
\hline \multirow{3}{*}{$\begin{array}{l}\text { Songzi, Jianli, } \\
\text { Honghu }\end{array}$} & Maximum & 100 & 100 & 100 & 100 & 100 & 40 & 100 & 90 \\
\hline & Minimum & 50 & 90 & 80 & 50 & 60 & 40 & 60 & 40 \\
\hline & Mean & 88.33 & 91.67 & 95.83 & 94.17 & 88.33 & 40 & 73.33 & 69.17 \\
\hline \multicolumn{10}{|c|}{ Use Stability Limited Type } \\
\hline Involved Counties & Metric & $\begin{array}{c}\text { Organic } \\
\text { Matter }\end{array}$ & $\mathrm{pH}$ & $\begin{array}{c}\text { Irrigation } \\
\text { Guarantee Rate }\end{array}$ & GDP & $\begin{array}{l}\text { Per Capita Net } \\
\text { Income of } \\
\text { Farmers }\end{array}$ & $\begin{array}{l}\text { Labor per Unit } \\
\text { Planted Area }\end{array}$ & $\begin{array}{l}\text { Distance to } \\
\text { Expressway }\end{array}$ & $\begin{array}{c}\text { Water } \\
\text { Resources Area }\end{array}$ \\
\hline Changyang, & Maximum & 100 & 100 & 100 & 100 & 100 & 100 & 100 & 100 \\
\hline Dianjun, Badong, & Minimum & 50 & 50 & 50 & 20 & 40 & 40 & 80 & 60 \\
\hline Hefeng & Mean & 86.07 & 75.36 & 74.29 & 65 & 71.43 & 44.29 & 88.57 & 71.79 \\
\hline \multicolumn{10}{|c|}{ Natural Quality and Use Convenience Limited Type } \\
\hline Involved Counties & Metric & $\mathrm{pH}$ & $\begin{array}{l}\text { Obstacle } \\
\text { Depth }\end{array}$ & $\begin{array}{c}\text { Irrigation } \\
\text { Guarantee Rate }\end{array}$ & $\begin{array}{l}\text { Labor per Unit of } \\
\text { Planted Area }\end{array}$ & Form Field & $\begin{array}{l}\text { Farmland } \\
\text { Continuity }\end{array}$ & $\begin{array}{l}\text { Distance to } \\
\text { Expressway }\end{array}$ & $\begin{array}{c}\text { Water } \\
\text { Resources Area }\end{array}$ \\
\hline \multirow{3}{*}{ Zhijiang, Dangyang } & Maximum & 100 & 100 & 100 & 40 & 100 & 100 & 80 & 100 \\
\hline & Minimum & 70 & 50 & 50 & 40 & 60 & 60 & 60 & 40 \\
\hline & Mean & 87.5 & 62.5 & 60.94 & 40 & 74.06 & 72.81 & 66.56 & 74.69 \\
\hline \multicolumn{10}{|c|}{ Natural Quality and Use Stability Limited Type } \\
\hline Involved Counties & Metric & $\begin{array}{c}\text { Profile } \\
\text { Configuration }\end{array}$ & $\mathrm{pH}$ & Obstacle Depth & $\begin{array}{c}\text { Irrigation } \\
\text { Guarantee Rate }\end{array}$ & GDP & $\begin{array}{c}\text { Per Capita Net } \\
\text { Income of Farmers }\end{array}$ & $\begin{array}{l}\text { Labor per Unit } \\
\text { Planted Area }\end{array}$ & Form Field \\
\hline \multirow{3}{*}{$\begin{array}{c}\text { Hanchuan, } \\
\text { Qianjiang, Shishou, } \\
\text { Jianli, Honghu }\end{array}$} & Maximum & 70 & 100 & 10 & 100 & 100 & 100 & 60 & 100 \\
\hline & Minimum & 50 & 50 & 50 & 50 & 60 & 60 & 40 & 60 \\
\hline & Mean & 60 & 73.89 & 78.33 & 79.44 & 68.89 & 78.89 & 43.33 & 86.67 \\
\hline
\end{tabular}




\section{Conclusions}

Evaluating and monitoring land quality is a complex and challenging undertaking [17]. It has become an important activity in China because of the requirement of identify the changes and the natural, socioeconomic attributes of UCL to protect land without specific decisions to perform project investment and land consolidation.

This paper establishes a proper comprehensive assessment framework of UCL for the south-central and southwestern portions of Hubei Province in China using the GALQ method. Assessment supplement 12 proposed land use indicators on the basis of the natural factors of GALQ. The weights are determined by the improved model of fuzzy Analytic Hierarchy Process (FAHP). The scores are determined by Natural breakpoint method to standardize the factor values and assigned different grades, which are implemented by ArcGIS. Use the coefficient correction idea, we complement the LUPC into calculating of land use correction index, re-divide the grade of CLQ.

The overall level of CLQ in the study area was moderate, slightly higher than the national average. Assessment supplement 12 proposed land use and production indicators and used the land use coefficient correction method to identify the external factors that cause the spatial variability within the study area. The CV is the most commonly used measure of soil variability $[45,55]$. It found that the spatial differences in the CV in mountainous areas is greater than that in plain areas, and the natural attributes of cultivated land resources are still the main factors that restrict the quality of UCL. In addition, the small-scale agricultural development pattern, which depends strongly on the labor force, was the key extrinsic factor restricting the improvement of regional comprehensive CLQ. The resulting fragmentation of the cultivated land, the disintegration of the farmland road network, and the intensive development of the highway network associated with urbanization are important factors that restrict the convenience and stability of cultivated land use.

The National Resource Inventory assessments are conducted at five-year intervals [56], as not all of the soil quality factors vary significantly with land use [56]. Since we have not investigated whether the changes in the LUPCs are significant, two-year intervals are proposed for monitoring UCL.

This research provided adequate information on land-quality differences, as well as the spatial variability and characteristics of extrinsic factors among different management systems, as the outcomes are comparable at different locations. This study provides a valid basis for achieving a national balance in the requisition and compensation of cultivated land and perform in gland management of UCL. This study makes a significant contribution towards providing the theoretical and technical references that are needed for the national project of the evaluation and monitoring of UCL.

Further study is needed to determine whether using ecological indicators. It can be used to evaluate the comprehensive quality of UCL to achieve the coordination of cultivated land production and ecological functions. We suggest that a decision support [47] from the environmental department to arrive at better informed land management decisions.

Acknowledgments: This work was supported by the National Key National Key R\&D Program of China (2016YFC0803106). The authors would like to thank Qingyun Du and Liming Jiao from Wuhan University for their valuable suggestions. We also thank the Department of Land and Resources of Hubei Province and Land Resources Bureau of the counties within the study area for providing the data and materials.

Author Contributions: Lina Peng conceived and designed the study with the support of Qingyun Du. All of the co-authors drafted and revised the article together. All of the authors read and approved the final manuscript.

Conflicts of Interest: The authors declare no conflict of interest.

\section{References}

1. Liu, Y.; Zhang, Y.; Guo, L. Towards realistic assessment of cultivated land quality in an ecologically fragile environment: A satellite imagery-based approach. Appl. Geogr. 2010, 30, 271-281. [CrossRef]

2. Eswaran, H.; Lal, R.; Reich, P. Land degradation: An overview. In Response to Land Degradation; Bridges, E.M., Oldeman, L.R., Penning De Vries, F.W.T., Scherr, J.S., Sombatpanit, S., Eds.; Science Publisher, Inc.: Enfield, NH, USA, 2001; pp. 20-35. 
3. Ayoubi, S.; Khormali, F.; Sahrawat, K.; Rodrigues, D.L.A. Assessing impacts of land use change on soil quality indicators in a loessial soil in Golestan Province, Iran. J. Agric. Sci. Technol. 2011, 13, 727-742.

4. Waswa, B.S.; Vlek, P.L.G.; Tamene, L.D.; Okoth, P.; Mbakaya, D.; Zingore, S. Evaluating indicators of land degradation in smallholder farming systems of Western Kenya. Geoderma 2013, 195, 192-200. [CrossRef]

5. Rao, P.S.C.; Wagenet, R.J. Spatial variability of pesticides in field soils: Methods of data analysis and consequences. Weed Sci. 1985, 33, 18-24.

6. Zacharias, S. Modeling Spatial Variability of Field-Scale Solute Transport in the Vadose Zone; Virginia Poly Technic Institute and State University: Blacksburgg, VA, USA, 1998.

7. Vieira, S.R.; Millete, J.; Topp, G.C.; Reynolds, W.D. Handbook for Geostatistical Analysis of Variability in Soil and Climate Data; Sociedade Brasileira de Ciência do Solo: Viçosa, Brazil, 2002.

8. Daba, S. An investigation of the physical and socio-economic determinants of soil erosion in the hararghe highlands, Eastern Ethiopia. Land Degrad. Dev. 2003, 14, 69-181. [CrossRef]

9. Tenge, A.; Graaff, D.J.; Hella, J. Social and economic factors affecing the adoption of soil and water conservation in West Usambara Highlands, Tanzania. Land Degrad. Dev. 2004, 15, 99-114. [CrossRef]

10. Pendleton, R.L. Are soils mapped under a given type name by the bureau of soils method closely similar to one another? Univ. Calif. Publ. Agric. Sci. 1919, 3, 3489-369.

11. Smith, F.H. An empirical law describing heterogeneity in the yield of agricultural crops. J. Agric. Sci. 1938, 28, 1-23. [CrossRef]

12. Beckett, P.H.T.; Webster, R. Soil variability: A review. Soils Fertil. 1971, 34, 1-15.

13. Webster, R. The development of pedometrics. Geoderma 1994, 62, 1-15. [CrossRef]

14. Nielsen, D.R. Spatial variability of field-measured soil-water properties. Hilgardia 1973, 42, 215-259. [CrossRef]

15. Xu, M.; Zhao, Y.; Liu, G.; Wilson, G.V. Identification of soil quality factors and indicators for the Loess Plateau of China. Soil Sci. 2006, 171, 400-413.

16. Tongway, D.J. Teaching the assessment of landscape function in the field: Enabling the design and selection of appropriate restoration techniques. Ecol. Restor. 2010, 28, 182-187. [CrossRef]

17. Rosa, D.D.l. Soil quality evaluation and monitoring based on land evaluation. Land Degrad. Dev. 2005, 16, 551-559. [CrossRef]

18. Food and Agriculture Organization (FAO). A Framework for Land Evaluation; FAO: Rome, Italy, 1976.

19. Nkedi-Kizza, P.; Gaston, L.A.; Selim, H.M. Extrinsic spatial variability of selected macronutrients in a sandy soil. Geoderma 1994, 63, 95-106. [CrossRef]

20. Dumanski, J. Criteria and indicators for land quality and sustainable land management. ITC J. 1997, 3, $216-222$.

21. Doran, J.; Parkin, T. Quantitative indicators of soil quality: A minimum data set. In Methods for Assessing Soil Quality; John, W.D., Alice, J.J., Eds.; Soil Science Society of America: Madison, WI, USA, 1996; Volume 49, pp. 25-38.

22. Cay, T. Arazi Duzenlemesi ve Mevzuati; Petek Ofset Konya: Konya, Turkey, 2001.

23. Pasakarnis, G.; Maliene, V. Towards sustainable rural development in central and eastern Europe: Applying land consolidation. Land Use Policy 2010, 27, 545-549. [CrossRef]

24. Cay, T.; Uyan, M. Evaluation of reallocation criteria in land consolidation studies using the analytic hierarchy process (AHP). Land Use Policy 2013, 30, 541-548. [CrossRef]

25. Caroline, C.; Olivier, E.; Sébastien, S.-B.; Florent, H.; Kristof, V.O.; Irène, L.; Joël, D.; Jean-Jacques, M. Quantifying and modelling the impact of land consolidation and field borders on soil redistribution in agricultural landscapes (1954-2009). Catena 2013, 110, 184-195.

26. Coelho, J.C.; Pinto, P.A.; Silva, L.M.D. A systems approach for the estimation of the effects of land consolidation projects (LCPs): A model and its application. Agric. Syst. 2001, 68, 179-195. [CrossRef]

27. Tong, L.-Y.; Hu, S.-G.; Yang, S.-F. A new method for arable land quality reevaluation in land consolidation areas. China Land Sci. 2015, 29, 60-66.

28. Dumanski, J.; Pieri, C. Land quality indicators: Research plan. Agric. Ecosyst. Environ. 2000, 81, 93-102. [CrossRef]

29. Nortcliff, S. Standardization of soil quality attributes. Agric. Ecosyst. Environ. 2002, 88, 161-168. [CrossRef]

30. Xu, K.; Jin, X.; Wu, D.; Zhou, Y. Cultivated land quality evaluation of land consolidation project based on agricultural land gradation. Trans. Chin. Soc. Agric. Eng. 2015, 31, 247-255.

31. Ma, J.-H.; Wu, K.-N.; Zhao, H.-F.; Xu, Y.; Liu, Q.-Q. Construction of cultivated land quality monitoring indicators of China. Guangdong Agric. Sci. 2012, 39, 74-78.

32. Li, Y.; Hu, X.; Qiao, J. An improved fuzzy ahp method. J. Northwest Univ. 2005, 35, 11-12. 
33. Wei, X.; Liu, Y.; Wang, N. Spaitial disparity pattern of land consolidation projects in Hubei province. Trans. Chin. Soc. Agric. Eng. 2014, 30, 195-203.

34. Ericksen, P.J.; McSweeney, K. Fine-scale analysis of soil quality for various land use and landforms in central Honduras. Am. J. Altern. Agric. 1999, 14, 146-157. [CrossRef]

35. Tesfahunegn, G.B. Soil quality indicators response to land use and soil management systems in northern Ethiopia's catchment. Land Degrad. Dev. 2013. [CrossRef]

36. Mairura, F.S.; Mugendi, D.N.; Mwanje, J.I.; Rarnisch, J.J.; Mbugua, P.K.; Chianu, J.N. Integrating scientific and farmers' evaluation of soil quality indicators in central Kenya. Geoderma 2007, 139, 134-143. [CrossRef]

37. Cao, J.-J.; Zhou, Y.; Ye, Q.-Q.; Yu, L.; Liu, Q. Analysis of spatial pattern changes of cultivated land resource in Jianghan Plain. Econ. Geogr. 2013, 33, 130-135.

38. Jingyao, M.; Yong, G.; Zhongqiu, Z.; Xiaolin, W.; Yongli, Z.; Yuehong, C.; Yongze, S. Poverty alleviation evaluation and spatial pattern analysis of Wuling Mountain. J. Geo-Inf. Sci. 2016, 18, 334-342.

39. Zhao, X.-L. The study on investigation exploitation and utilization of wild ornamental plant resources in South-Western Hubei. J. Mt. Agric. Biol. 2001, 20, 117-123.

40. Kammerbauer, J.; Ardon, C. Land use dynamics and landscape change pattern in a typical watershed in the hillside region of central Honduras. Agric. Ecosyst. Environ. 1999, 75, 93-100. [CrossRef]

41. Chen, J.-G.; Tian, D.-L.; Yan, W.-D.; Xiang, W.-H.; Fang, X. Study on organic carbon storage, density, and their impact factors based on region scale in Southwest Hubei, China. J. Cent. South Univ. For. Technol. 2011, 31, 57-62.

42. Madelene, O.A.; Chen, D.L. Land-use change: Impacts of climate variations and policies among small-scale farmers in the Loess Plateau, China. Land Use Policy 2006, 23, 361-371.

43. Smit, H.J.; Metzger, M.J.; Ewert, F. Spatial distribution of grassland productivity and land use in Europe. Agric. Syst. 2008, 98, 208-219. [CrossRef]

44. Wang, H.; Cheng, F.; Zhang, Z.; Yun, W. Differential characteristics of cultivated land grade and its effect on cultivated land protection in China. Trans. CSAE 2011, 27, 1-8.

45. Wilding, L.P. Spatial Variability: Its Documentation, Accommodation, and Implication to Soil Surveys; Pudoc: Wageningen, The Netherlands, 1985.

46. Gao, H.; Wang, L.; Luo, C.; Zhang, J.; Ni, H. Analysis of soil nutrient characteristics of Sanjiang Plain. Chin. Agric. Sci. Bull. 2013, 29, 254-262.

47. Lima, A.C.R.; Brussaard, L.; Totola, M.R.; Hoogmoed, W.B.; De Goede, R.G.M. A functional evaluation of three indicator sets for assessing soil quality. Appl. Soil Ecol. 2013, 64, 194-200. [CrossRef]

48. Momtaz, H.R.; Jafarzadeh, A.A.; Torabi, H.; Qustan, S.; Samadi, A. An assessment of the variation in soil properties within and between landform in the Amol region, Iran. Geoderma 2009, 149, 10-18. [CrossRef]

49. Seyfried, M.S.; Wilcox, B.P. Scale and nature of spatial variability: Field examples having implications for hydrologic modeling. Water Resour. Res. 1995, 31, 173-184. [CrossRef]

50. Jiang, P.; Thelen, K.D. Effect of soil and topographic properties on crop yield in a north-central corn-soybean cropping system. Agron. J. 2004, 96, 252-258. [CrossRef]

51. Hue, N.V.; Licudine, D.l. Amelioration of subsoil acidity through surface application of organic manures. J. Environ. Qual. 1999, 28, 623-663. [CrossRef]

52. O'Hallorans, J.M.; Muñoz, M.A.; Marquez, P.E. Chicken manure as an amendment to correct soil acidity and fertility. J. Agric. Univ. P. R. 1997, 81, 1-8.

53. Ruben, N.L.; Andrew, J.P.; Robert, N.S. What drives land-use change in the United States? A national analysis of landowner decisions. Land Econ. 2008, 84, 529-550.

54. Vesterby, M.; Krupa, K.S. Major Uses of Land in the United States: 1997; U.S. Department of Agriculture, Economic Research Service: Washington, DC, USA, 1995.

55. Oluwole, A. Variability of soils developed on migmatites in a part of the middle belt of Nigeria. Appl. Geogr. 1985, 5, 309-323.

56. Brejda, J.J.; Moorman, T.B.; Karlen, D.L.; Dao, T.H. Identification of regional soil quality factors and indicators: I. Central and southern high plains. Soil Sci. Soc. Am. J. 2000, 64, 2115-2124. [CrossRef]

(C) 2017 by the authors. Licensee MDPI, Basel, Switzerland. This article is an open access article distributed under the terms and conditions of the Creative Commons Attribution (CC BY) license (http:/ / creativecommons.org/licenses/by/4.0/). 